\title{
GMR
}

\section{Different responses of vanillic acid, a phenolic compound, in HTC cells: cytotoxicity, antiproliferative activity, and protection from DNA-induced damage}

\author{
I.V. Almeida, F.M.L. Cavalcante and V.E.P. Vicentini \\ Laboratório de Mutagênese e Monitoramento Ambiental, \\ Departamento de Biotecnologia, Genética e Biologia Celular, \\ Universidade Estadual de Maringá, Maringá, PR, Brasil \\ Corresponding author: I.V. Almeida \\ E-mail: igoralmeida.bio@gmail.com
}

Genet. Mol. Res. 15 (4): gmr15049388

Received September 28, 2016

Accepted November 11, 2016

Published December 19, 2016

DOI http://dx.doi.org/10.4238/gmr15049388

Copyright (C) 2016 The Authors. This is an open-access article distributed under the terms of the Creative Commons Attribution ShareAlike (CC BY-SA) 4.0 License.

\begin{abstract}
The consumption of healthy and natural foods has increased over the last few years, primarily because these foods are rich in substances with biological properties of interest, such as exerting anticancer effects and decreasing oxidative stress in living tissues. These foods support adequate nutrition, maintain health, and improve quality of life. Vanillic acid (VA) is a phenolic compound used widely in the food industry as a flavoring, preservative, and food additive. VA can be found in various cereals, whole grains, fruits, herbs, green tea, juices, beers, and wines and possesses antioxidant, hepatoprotective, cardioprotective, and antiapoptotic activities. Studying the cytotoxicity as well as the mutagenic and antimutagenic effects of different concentrations of VA in Rattus norvegicus hepatoma cells (HTC) can
\end{abstract}


identify new cellular activities of this substance. Concentrations up to 100 $\mu \mathrm{M}$ VA are not cytotoxic to HTC cells in a MTT [3-(4,5-dimethilthiazol2-yl)-2,5-diphenil tetrazolium bromide] assay after 96-h exposure; therefore, VA does not compromise mitochondrial activity. Similarly, concentrations up to $500 \mu \mathrm{M}$ do not compromise plasma membrane integrity. VA at 10 and $50 \mu \mathrm{M}$ showed no mutagenic/clastogenic effects, as no significant micronuclei induction was observed. VA 10 $\mu \mathrm{M}$ presented no antiproliferative activity and reduced the cytotoxicity induced by benzo[a]pyrene. The antimutagenic activity of $10 \mu \mathrm{M}$ VA was observed by the simultaneous, pre-, and post-treatments, as the phenolic compound significantly reduced the frequency of micronuclei induced by the mutagen. These results indicate that VA exerts different responses in HTC cells. Low concentrations present no cytotoxic, mutagenic, or antiproliferative effects and protect cells from DNA damage.

Key words: Antimutagenicity; Cell viability; Clastogenicity; Micronuclei; Mutagenicity

\section{INTRODUCTION}

Plant secondary metabolites are derived from the products of primary metabolism but are not directly involved in the basic processes of growth and development. Many of these products play important roles in the interaction between plants and the environment, particularly with the biotic environment, where such substances may act as agents that attract pollinators or seed dispersers, defend against natural enemies or parasites, or serve as allelochemicals during competition. However, many of the functions and benefits plants derive from secondary metabolites remain unknown (Kroymann, 2011; Russell and Duthie, 2011).

Vanillic acid (4-hydroxy-3-methoxybenzoic acid; VA) is a phenolic compound produced by secondary metabolism in plants, and is widely used in the food industry as a flavoring, food additive, and preservative, and in perfumery (Figure 1). Its pleasant vanilla aroma is due to its molecular structure, which corresponds to the oxidized form of the aldehyde vanillin (vanilla). VA can be found in many foods, such as rice, wheat, mango, strawberry, sugarcane, herbs and spices, beer, wine, teas, and juices (Zheng and Wang, 2001; Brindzová et al., 2009; Russell et al., 2009; Gitzinger et al., 2012; Jun et al., 2012; Palafox-Carlos et al., 2012; Alves et al., 2016).<smiles>COc1cc(C(=O)O)ccc1O</smiles>

Figure 1. Structure of vanillic acid.

Genetics and Molecular Research 15 (4): gmr15049388 
VA exerts strong antioxidant action, exhibits hypotensive, cardioprotective, hepatoprotective, and antiapoptotic activities, inhibits snake venom, and has roles in gene regulation (Dhananjaya et al., 2006; Huang et al., 2008; Dhananjaya et al., 2009; Itoh et al., 2009; Chou et al., 2010; Kim et al., 2010; Kumar et al., 2011; Prince et al., 2011). These biological actions suggest that VA can act as a functional food by contributing to the welfare and health of the population (Navarro et al., 2015) and as a nutraceutical by aiding the treatment and prevention of degenerative diseases, such as atherosclerosis and cancer (Das et al., 2012).

However, studies investigating the cytotoxic activity of VA, its interaction with and ability to change the genetic material of cells (such as the appearance of double-stranded DNA breaks), and its ability to prevent such events are lacking. Only a few studies on these potential roles of VA have been reported in the literature; therefore, we sought to identify the properties of this phenolic compound, which is present even at low concentrations in many natural and processed foods that are consumed daily by human populations. This study determined the cytotoxic effects of VA using the MTT [3-(4,5-dimethilthiazol-2-yl)-2,5-diphenil tetrazolium bromide] assay and investigated the cell viability, mutagenic activity, and antimutagenic activity of VA using the cytokinesis-block micronucleus assay in Rattus norvegicus hepatoma cells (HTC) cultured in vitro. These cells represent an easy and low cost cultivation system, and possess a metabolism similar to that of human cells.

\section{MATERIAL AND METHODS}

\section{Cell lines}

HTC cells were provided by the Rio de Janeiro Cell Bank, Brazil (BCRJ catalogue No. 0112). The cells were grown in culture flasks $\left(25 \mathrm{~cm}^{2}\right)$ with $10 \mathrm{~mL}$ DMEM (Dulbecco's Modified Eagle Medium) culture medium (Invitrogen, Carlsbad, CA, USA) supplemented with $10 \%$ fetal bovine serum (Invitrogen), $0.01 \%$ penicillin, and streptomycin (Invitrogen), in a BOD incubator at $37^{\circ} \mathrm{C}$. All treatments were performed in three independent repetitions.

\section{Chemicals}

VA (97\%; CAS 121-34-6), benzo[a]pyrene (B[a]P; 96\%; CAS 50-32-8), doxorubicin (DXR 98\%; CAS 25316-40-9), methyl methanesulfonate (MMS; 99\%; CAS 66-27-3), cytochalasin-B (CytB; 98\%; CAS 14930-96-2), dimethyl sulfoxide (DMSO; 99.7\%; CAS 6768-5), and MTT [3-(4,5-dimethilthiazol-2-yl)-2,5-diphenil tetrazolium bromide; 98\%; CAS 298-93-1] were purchased from Sigma (St. Louis, MO, USA). Trypan blue dye was purchased from Invitrogen. VA was diluted in DMEM to a final concentration of $1000 \mu \mathrm{M}$. The other concentrations of VA $(1,10,50,100$, and $500 \mu \mathrm{M})$ were prepared by diluting this solution in complete culture medium.

\section{Cytotoxicity assay (MTT)}

To detect cytotoxicity, a MTT assay was performed according to the protocol suggested by Mosmann (1983) with modifications. Wells of 24 -well cell culture plates were seeded with $5 \times 10^{4}$ cells; the control wells contained no cells (blank). The cells were cultured for $24 \mathrm{~h}$ with $2 \mathrm{~mL}$ DMEM supplemented with $10 \%$ fetal bovine serum. After this period, the culture

Genetics and Molecular Research 15 (4): gmr15049388 
medium was discarded, and $2 \mathrm{~mL}$ fresh medium containing the appropriate agent was added. The following groups were used: negative control (CO-, $50 \mu \mathrm{L}$ DMEM), cytotoxic agent (MMS, $150 \mu \mathrm{M}$ ), and VA (concentrations of 1, 10, 50,100, and $500 \mu \mathrm{M}$ ). The blank wells were treated with $500 \mu \mathrm{M}$ VA. The cells were then incubated for $24,48,72$, and $96 \mathrm{~h}$ following this, the DMEM was replaced with $0.5 \mathrm{~mL}$ serum-free medium plus $0.167 \mathrm{mg} / \mathrm{mL}$ MTT. The plate was incubated for an additional $4 \mathrm{~h}$; then, the MTT-containing medium was discarded, and each well received $0.3 \mathrm{~mL}$ DMSO for formazan crystal solubilization. The absorbance was measured in a microplate reader at $550 \mathrm{~nm}$. The absorbance data were normalized to that of the negative control ( $\left.\mathrm{Abs}_{\text {treatment }} / \mathrm{Abs}_{\text {control }} \mathrm{x} 100\right)$.

\section{Trypan blue exclusion cell viability assay}

Cell viability was assessed on 24-well cell culture plates. In each well, $2.5 \times 10^{4}$ cells were seeded in $2 \mathrm{~mL}$ complete culture medium plus the following treatments: $\mathrm{CO}-(50$ $\mu \mathrm{L}$ culture medium), cytotoxic agent (DXR, $10 \mu \mathrm{g} / \mathrm{mL}$ ), and VA $(1,10,50,100$, and 500 $\mu \mathrm{M})$. The cells were incubated for $24 \mathrm{~h}$, trypsinized, and resuspended in $0.5 \mathrm{~mL}$ culture medium. An aliquot of the cellular suspension $(20 \mu \mathrm{L})$ was homogenized with trypan blue $(0.4 \%)$ dye in a $1: 1$ ratio. The cells were quantified on a Neubauer chamber hemocytometer. Data are presented as the relative percentage of viability compared to the negative control $\left(\mathrm{V}_{\text {treatment }} / \mathrm{V}_{\text {control }} \times 100\right)$.

\section{Cytokinesis-block micronucleus assay}

For the mutagenicity experiment, $1 \times 10^{6}$ cells were cultured in $5 \mathrm{~mL}$ complete culture medium per flask. After cell-cycle stabilization, the following groups were used: $\mathrm{CO}-(100 \mu \mathrm{L}$ culture medium), micronucleus inducer (B[a]P, $10 \mu \mathrm{g} / \mathrm{mL})$, and VA $(10,50,100 \mu \mathrm{M})$. CytB (3 $\mu \mathrm{g} / \mathrm{mL}$ ) was added to obtain binucleated cells.

For the antimutagenicity assay, different treatments containing $10 \mu \mathrm{M}$ VA were used; the treatment lasted for $24 \mathrm{~h}$ (simultaneous; SIM) or $48 \mathrm{~h}$ (SIM; pre-treatment; PRE; and posttreatment; POST) (Figure 2).

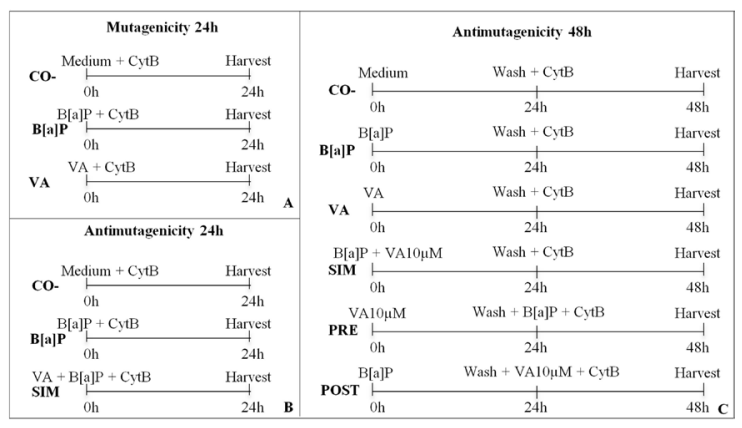

Figure 2. Treatments performed at $24 \mathrm{~h}$ (A. mutagenesis; B. antimutagenesis) and $48 \mathrm{~h}$ (C. antimutagenesis). $24 \mathrm{~h}$ : CO- (negative control: $100 \mu \mathrm{L}$ culture medium $+3 \mu \mathrm{g} / \mathrm{mL}$ CytB); B $[\mathrm{a}] \mathrm{P}(10 \mu \mathrm{g} / \mathrm{mL}+\mathrm{CytB}) ;$ and SIM $(10 \mu \mathrm{M}$ VA $+10 \mu \mathrm{g} / \mathrm{mL} \mathrm{B}[\mathrm{a}] \mathrm{P}+\mathrm{CytB}) .48 \mathrm{~h}$ : CO- (negative control: $100 \mu \mathrm{L}$ culture medium); $\mathrm{B}[\mathrm{a}] \mathrm{P}(10 \mu \mathrm{g} / \mathrm{mL}) ; \mathrm{VA}(10 \mu \mathrm{M}) ;$ SIM $(10 \mu \mathrm{M} \mathrm{VA}+10 \mu \mathrm{g} / \mathrm{mL}$ B[a]P); PRE $(10 \mu \mathrm{M}$ VA); and POST $(10 \mu \mathrm{g} / \mathrm{mL} \mathrm{B}[\mathrm{a}] \mathrm{P})$. After washing, complete culture medium + CytB was added to all flasks; additional treatments were added to the PRE $(10 \mu \mathrm{g} / \mathrm{mL} \mathrm{B}[\mathrm{a}] \mathrm{P})$ and POST $(10 \mu \mathrm{M}$ VA) groups at $48 \mathrm{~h} . \mathrm{N}=3$.

Genetics and Molecular Research 15 (4): gmr15049388 
The cells $\left(1 \times 10^{6}\right)$ were seeded in $5 \mathrm{~mL}$ complete culture medium per flask, and the treatments were performed after one cell cycle stabilization. In the 48 -h treatments, all flasks were washed twice with $5 \mathrm{~mL}$ PBS after $24 \mathrm{~h}$, and then, $5 \mathrm{~mL}$ complete culture medium and CytB $(3 \mu \mathrm{g} / \mathrm{mL})$ were added for a further $24 \mathrm{~h}$. The PRE group also received B[a]P $(10 \mu \mathrm{g} /$ $\mathrm{mL})$, and the POST group received VA $(10 \mu \mathrm{M})$.

The cells were harvested after $24 \mathrm{~h}$ in steps $\mathrm{A}$ and $\mathrm{B}$, and at $48 \mathrm{~h}$ in step $\mathrm{C}$ to ensure they had completed one or two division cycles under all treatments, respectively, according to the method described by Salvadori et al. (2003). Briefly, the cells were trypsinized, pre-fixed with a drop of formaldehyde, centrifuged (1000 rpm, $5 \mathrm{~min})$, hydrated (1\% sodium citrate), centrifuged again, and fixed in methanol-acetic acid (3:1). Slides were prepared by placing one drop of the material on a slide covered with a film of cold distilled water. After drying at room temperature, the slides were stained with Giemsa (5\%), dried, and stored in the refrigerator.

One-thousand binucleated cells were counted per replicate to determine the incidence of micronuclei. To determine the cytokinesis-block proliferation index (CBPI), at least 500 cells per repeat were counted; mono-, bi-, and multinucleate cells were differentiated; and the index was calculated with the following formula:

$$
\text { CBPI }(\%)=\text { number of mononuclear cells }+ \text { bi }(x 2)+\text { multi }(x 3) / \text { total cells }
$$

The percentage cytostasis was calculated using the following formula:

$$
\text { Cytostasis } \left.(\%)=100-100\left[\left(\mathrm{CBPI}_{\text {Treatment }}-1\right) \div\left(\mathrm{CBPI}_{\text {Control }}-1\right)\right] \quad \text { (Equation } 2\right)
$$

The percentage damage reduction in the antimutagenicity test was determined by the following formula:

$$
\begin{gathered}
\text { Reduction }(\%)=[(\text { Number of cells with } \mathrm{MN} \text { in } \mathrm{A}-\mathrm{Number} \text { of cells with } \mathrm{MN} \text { in B) } \times 100] \\
/(\text { Number of cells with } \mathrm{MN} \text { in } \mathrm{A}-\text { Number of cells with } \mathrm{MN} \text { in C) } \\
\text { (Equation 3) }
\end{gathered}
$$

where $\mathrm{A}$ is the damage-inducing agent; $\mathrm{B}$ is the treatment, and $\mathrm{C}$ is the negative control.

\section{Statistical analysis}

The absorbance data obtained from the MTT assay, the percentage of viable cells in the cell viability test, and the average number of micronuclei were evaluated using ANOVA followed by a Tukey test $(\alpha=0.05)$ with the GrafPad Instat program.

\section{RESULTS}

\section{MTT test}

The highest VAconcentration tested $(500 \mu \mathrm{M})$ resulted in a statistically significant difference $(\mathrm{P}<0.0001)$ in the absorbance value compared to the CO- after $96 \mathrm{~h}$ (Figure 3). Treatment with MMS resulted in statistically significant differences at all exposure times $(\mathrm{P}<0.0001)$, confirming the responsiveness of the test for substances that interfere with mitochondrial activity.

Genetics and Molecular Research 15 (4): gmr15049388 


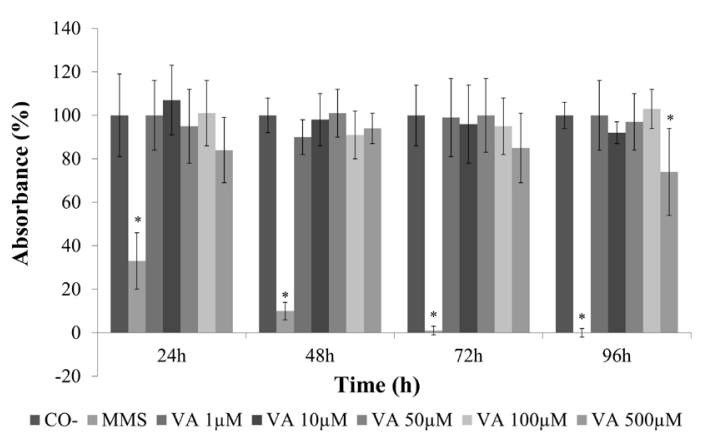

Figure 3. Effect of VA on the activity of mitochondrial succinate dehydrogenase in HTC cells at different times determined by MTT [3-(4,5-dimethilthiazol-2-yl)-2,5-diphenil tetrazolium bromide] assay. The data were normalized (percentage) to the negative control. The values represent the means \pm standard deviation; $\mathrm{N}=3$ wells of $5 \times 10^{4}$ cells per well. CO-: negative control (50 $\mu \mathrm{L}$ culture medium); MMS (150 $\left.\mu \mathrm{M}\right)$; and VA $(1,10,50,100$, and $500 \mu \mathrm{M}) . *$ Statistically significant difference compared to the negative control $(\mathrm{P}<0.0001)$.

\section{Trypan blue exclusion viability assay}

Treatment with VA, at any of the concentrations evaluated, did not significantly affect cell viability as compared with the negative control (Figure 4). The mean cell viability in response to DXR was $<80 \%$ for the same period of exposure, which was significantly different from that in the $\mathrm{CO}-(\mathrm{P}<0.0001)$.

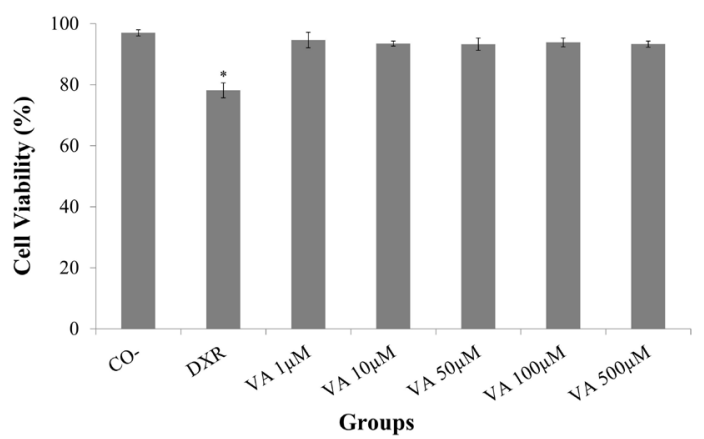

Figure 4. Effect of vanillic acid (VA) on plasma membrane viability of HTC cells after treatment for $24 \mathrm{~h}$. The data are reported as the percentage of live cells. The values represent the means \pm standard deviation; $\mathrm{N}=3$ wells of 2.5 x $10^{4}$ cells per well. CO-: negative control (50 $\mu \mathrm{L}$ culture medium); DXR $(10 \mu \mathrm{g} / \mathrm{mL})$; and VA $(1,10,50,100$, and $500 \mu \mathrm{M})$. *Statistically significant difference compared to the $\mathrm{CO}-(\mathrm{P}<0.0001)$.

\section{Cytokinesis-block micronucleus assay}

No significant differences were observed in the average number of micronuclei in HTC cells between the 10 and $50 \mu \mathrm{M}$ VA treatments and the CO-. However, $100 \mu \mathrm{M}$ VA resulted a significant increment of micronuclei compared with the control $(\mathrm{P}<0.001)$. Furthermore, no significant differences were identified between the B[a]P and $100 \mu \mathrm{M}$ VA groups (Figure 5). 


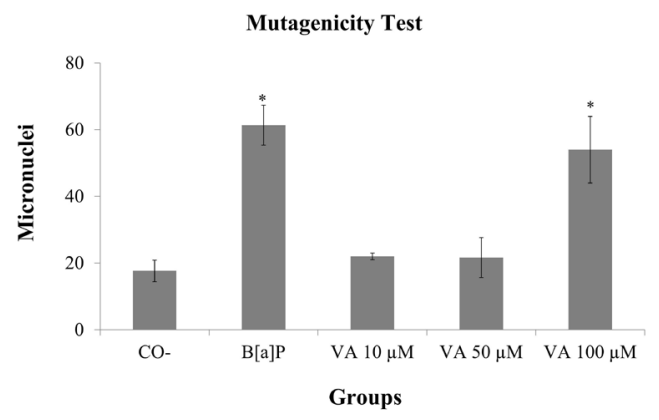

Figure 5. Effect of vanillic acid (VA) on micronuclei induction in HTC cells treated for $24 \mathrm{~h}$. The values represent the means \pm standard deviation; $\mathrm{N}=3$ flasks with $1 \times 10^{6}$ cells; 3000 cells analyzed. CO-: negative control (100 $\mu \mathrm{L}$ culture medium); B[a]P $(10 \mu \mathrm{g} / \mathrm{mL})$; and VA $(10,50,100 \mu \mathrm{M}) . *$ Statistically significant difference compared to $\mathrm{CO}-(\mathrm{P}<0.001)$.

No statistically significant differences in CBPI were identified between the treatments and the control. A relatively low number of cytostatic cells $(5.55 \%)$ was observed following treatment with $\mathrm{B}[\mathrm{a}] \mathrm{P}$ compared to the negative control. However, treatment with 10,50 , and $100 \mu \mathrm{M}$ VA resulted in an increase in the proportion of dividing cells compared with the control $(0.15,6.16$, and $4.65 \%$, respectively), as represented by the negative percentage of cytostasis (Table 1).

Table 1. Cytokinesis-block proliferation index (CBPI) and the percentage of cytostasis in HTC cells treated with VA for $24 \mathrm{~h}$.

\begin{tabular}{l|c|c|c}
\hline Groups & Total analyzed cells & Mean CBPI \pm SD & Cytostasis (\%) \\
\hline CO- & 1500 & $1.67 \pm 0.08$ & - \\
\hline B $[$ a]P & 1500 & $1.63 \pm 0.04$ & 5.55 \\
\hline VA $10 \mu \mathrm{M}$ & 1500 & $1.67 \pm 0.10$ & -0.15 \\
\hline VA $50 \mu \mathrm{M}$ & 1500 & $1.71 \pm 0.01$ & -6.16 \\
\hline VA $100 \mu \mathrm{M}$ & 1500 & $1.69 \pm 0.07$ & -4.65 \\
\hline
\end{tabular}

CO-: negative control $(100 \mu \mathrm{L}$ culture medium); $\mathrm{B}[\mathrm{a}] \mathrm{P}(10 \mu \mathrm{g} / \mathrm{mL})$; VA $(10,50,100 \mu \mathrm{M}) . \mathrm{N}=3$. Negative cytostasis corresponds to the stimulation of proliferation.

A statistically significant difference between the SIM and B[a]P treatments $(\mathrm{P}<0.05)$ was observed in the antimutagenicity test $(24 \mathrm{~h})$. When the number of cells with micronuclei was considered, the reduction was $57.14 \%$. For the 48 -h treatment, no statistically significant difference between the control group and the VA-only treatment was identified. In addition, all VA treatments were able to significantly reduce the frequency of micronucleated cells induced by $\mathrm{B}[\mathrm{a}] \mathrm{P}(\mathrm{P}<0.05)$. The greatest reduction in cells with micronuclei occurred with SIM treatment $(58.20 \%)$, followed by PRE (46.27\%), and POST (22.39\%) treatment (Figure 6).

No significant differences in CBPI were identified between treatments and the CO(Table 2) after 24 and $48 \mathrm{~h}$. For the 24-h treatment, SIM treatment caused a statistically significant difference $(\mathrm{P}<0.05)$ compared to the negative control, such that the level of cell proliferation increased.

Treatment with $\mathrm{B}[\mathrm{a}] \mathrm{P}$ only for 24 and $48 \mathrm{~h}$ led to 16.56 and $16.27 \%$ cytostatic cells, respectively (Table 2). The 24-h SIM treatment resulted in negative cytostasis and increased cell proliferation by $18.14 \%$, while the different 48 -h treatments reduced proliferation by 9.32\% (SIM), 10.74\% (PRE), and 7.11\% (POST) of cells treated with VA and B[a]P. 


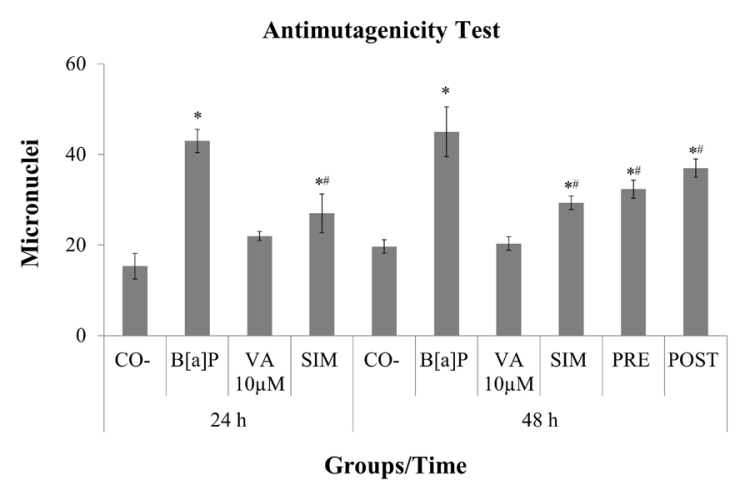

Figure 6. Effect of VA on the reduction of total MN induced by B[a]P in HTC cells with different types and timing of treatments. The values represent the means \pm standard deviation; $\mathrm{N}=3$ flasks with $1 \times 10^{6}$ cells; 3000 cells analyzed. $24 \mathrm{~h}$ : CO- (negative control: $100 \mu \mathrm{L}$ culture medium $+3 \mu \mathrm{g} / \mathrm{mL}$ CytB); B $[\mathrm{a}] \mathrm{P}(10 \mu \mathrm{g} / \mathrm{mL}+\mathrm{CytB})$; VA $(10 \mu \mathrm{M})$; and SIM $(10 \mu \mathrm{M}$ VA $+10 \mu \mathrm{g} / \mathrm{mL}$ B[a]P $+\mathrm{CytB}) .48 \mathrm{~h}$ : CO- (negative control: $100 \mu \mathrm{L}$ culture medium); $\mathrm{B}[\mathrm{a}] \mathrm{P}(10 \mu \mathrm{g} / \mathrm{mL}) ; \mathrm{VA}(10 \mu \mathrm{M}) ; \mathrm{SIM}(10 \mu \mathrm{M}$ VA $+10 \mu \mathrm{g} / \mathrm{mL}$ B[a]P); PRE $(10 \mu \mathrm{M} \mathrm{VA}) ;$ and POST $(10 \mu \mathrm{g} / \mathrm{mL}$ B[a] $\mathrm{P})$. After washing, complete culture medium $+\mathrm{CytB}$ was added to all wells; additional treatments were added to the PRE $(10 \mu \mathrm{g} / \mathrm{mL} \mathrm{B}[\mathrm{a}] \mathrm{P})$ and POST $(10 \mu \mathrm{M} \mathrm{VA})$ groups at $48 \mathrm{~h} .{ }^{*}$ Statistically significant difference compared to $\mathrm{CO}-(\mathrm{P}<0.05)$. "Statistically significant difference compared to $\mathrm{B}[\mathrm{a}] \mathrm{P}(\mathrm{P}<0.05)$.

Table 2. Cytokinesis-block proliferation index (CBPI) and the percentage of cytostasis (compared to the negative control HTC cells) under different types of VA treatment for 24 and $48 \mathrm{~h}$.

\begin{tabular}{l|l|c|c|c}
\hline Time & Groups & Total analyzed cells & Mean CBPI \pm SD & Cytostasis (\%) \\
\hline \multirow{4}{*}{$24 \mathrm{~h}$} & CO- & 1500 & $1.63 \pm 0,03$ & - \\
\cline { 2 - 5 } & B[a]P & 1500 & $1.53 \pm 0.02$ & 16.56 \\
\cline { 2 - 5 } & VA 10 $\mu \mathrm{M}$ & 1500 & $1.67 \pm 0.10$ & -0.15 \\
\cline { 2 - 5 } & SIM & 1500 & $1.75 \pm 0.06^{*}$ & -18.14 \\
\hline \multirow{4}{*}{$48 \mathrm{~h}$} & CO- & 1500 & $1.63 \pm 0.03$ & - \\
\cline { 2 - 5 } & B[a]P & 1500 & $1.53 \pm 0.09$ & 6.00 \\
\cline { 2 - 5 } & VA 10 $\mu \mathrm{M}$ & 1500 & $1.59 \pm 0.01$ & 9.32 \\
\cline { 2 - 5 } & SIM & 1500 & $1.57 \pm 0.04$ & 10.74 \\
\cline { 2 - 5 } & PRE & 1500 & $1.56 \pm 0.03$ & 7.11 \\
\cline { 2 - 5 } & POST & 1500 & $1.59 \pm 0.03$ & \\
\hline
\end{tabular}

24 h: CO- (negative control: $100 \mu \mathrm{L}$ culture medium $+3 \mu \mathrm{g} / \mathrm{mL}$ CytB); B[a]P $(10 \mu \mathrm{g} / \mathrm{mL}+\mathrm{CytB}) ; \mathrm{VA}(10 \mu \mathrm{M})$; and SIM $(10 \mu \mathrm{M}$ VA $+10 \mu \mathrm{g} / \mathrm{mL} \mathrm{B}[\mathrm{a}] \mathrm{P}+\mathrm{CytB}) .48 \mathrm{~h}$ : CO- (negative control: $100 \mu \mathrm{L}$ culture medium); B[a]P $(10 \mu \mathrm{g} / \mathrm{mL}) ; \mathrm{VA}(10 \mu \mathrm{M}) ; \mathrm{SIM}(10 \mu \mathrm{M}$ VA $+10 \mu \mathrm{g} / \mathrm{mL} \mathrm{B}[\mathrm{a}] \mathrm{P}) ;$ PRE $(10 \mu \mathrm{M} \mathrm{VA})$; and POST $(10 \mu \mathrm{g} / \mathrm{mL}$ B[a]P). After washing, complete culture medium + CytB was added to all wells; PRE received $10 \mu \mathrm{g} / \mathrm{mL}$ B[a]P, and POST received $10 \mu \mathrm{M} \mathrm{VA}$, at $48 \mathrm{~h} . \mathrm{N}=3$. Negative cytostasis corresponds to the stimulation of proliferation. *Statistically significant difference compared to $\mathrm{CO}-(\mathrm{P}<0.05)$.

\section{DISCUSSION}

Phenolic compounds are important components of the human diet due to their anticancer properties and their potent antioxidant action in living tissues, which could help to reduce the risk of developing chronic diseases.

Regarding the ability of VA to influence cell viability at the mitochondrial activity level as estimated by the MTT assay, VA was not cytotoxic to HTC cells at any concentration $(1,10,50$, and $100 \mu \mathrm{M})$ or after any exposure times $(24,48,72$, and $96 \mathrm{~h})$. The absorbance observed following treatment with $500 \mu \mathrm{M}$ VA for $96 \mathrm{~h}$ was significantly different from that of the $\mathrm{CO}$-, indicating lower mitochondrial activity and, consequently, cytotoxicity in response

Genetics and Molecular Research 15 (4): gmr15049388 
to this treatment $(\mathrm{P}<0.0001)$. The determination of cytotoxicity is critical for toxicological studies that investigate DNA damage because a reduction in mitochondrial activity may lead to the activation of intrinsic apoptosis pathways, resulting in DNA fragmentation.

Chen et al. (2008) isolated several compounds, including VA, from the medicinal plant Bulbophyllum odoratissimum and tested their cytotoxicity by the MTT assay following 72-h exposure in several human cell lines, including leukemia (K562 and HL-60), lung adenocarcinoma (A549), and hepatoma (BEL-7402) cells. Similar to our study, only $>600 \mu \mathrm{M}$ VA reduced the absorbance by $50 \%$ compared to the control, indicating low cytotoxicity of this compound. Our results were consistent with those of Chou et al. (2010) who found no cytotoxic effect of 20 or 50 $\mu \mathrm{M}$ VA in murine melanoma cells (B16F0) or human fibroblasts (Hs68) after $72 \mathrm{~h}$ of exposure.

The cytotoxicity of VA was also evaluated in the present study using the trypan blue exclusion test. HTC cells treated with VA $(1,10,50,100$, and $500 \mu \mathrm{M})$ for $24 \mathrm{~h}$ showed no damage at the plasma membrane level (viability higher than $90 \%$ ) compared to the CO-. Kanski et al. (2002) also found that $50 \mu \mathrm{M}$ VA had no cytotoxic effect using rat hippocampus embryonic cells exposed for $24 \mathrm{~h}$.

The level of DNA damage induced by VA was determined using the cytokinesisblock micronucleus assay, which permits the identification of micronuclei in cells that have undergone a nuclear division cycle during exposure to treatment, indicating the mechanism for clastogenicity. Because no cytotoxic activity was observed in HTC cells treated with 10, 50 , and $100 \mu \mathrm{M}$ VA, we chose to use the cells in a mutagenicity test. At concentrations of 10 and $50 \mu \mathrm{M}$, VA did not significantly induce micronuclei $(22 \pm 1$ and $21.67 \pm 7.37$ micronuclei, respectively) compared to the CO- $(17.67 \pm 3.21)$. However, $100 \mu \mathrm{M}$ VA was as effective at inducing micronuclei $(54 \pm 1.13)$ as treatment with the mutagen $\mathrm{B}[\mathrm{a}] \mathrm{P}(61.33 \pm 6.81)$. These data indicate that even non cytotoxic concentrations of VA, as observed by the MTT and cell viability assays, could be mutagenic/clastogenic and interact with DNA molecules or other related enzymes in HTC cells, inducing a larger number of micronuclei.

Nevertheless, the safety of VA has been questioned by some authors. Erdem et al. (2012) observed that $12 \mu \mathrm{M}$ VA was genotoxic to human lymphocytes using the micronucleous test and comet assay, while a concentration of $6 \mu \mathrm{M}$ was not genotoxic. Based on our results, these findings show that VA may induce DNA-damage in hepatoma cells at higher concentrations than in human lymphocytes, probably because of the different responses induced by VA in normal and cancer cell lines. Phenolic compounds should not be considered as pure antioxidants because under certain conditions, they can also display pro-oxidant activity (Erdem et al., 2012). This may have occurred in the present study, resulting in the cytotoxic and mutagenic effects of VA at 500 and $100 \mu \mathrm{M}$, respectively. However, Taner et al. (2016) observed no cytotoxicity or genotoxicity in Chinese hamster ovary cells and human lymphocytes at concentrations up to $168 \mathrm{mM}$ VA by the micronucleus test and comet assay.

To investigate the antimutagenicity of VA, we used a concentration of $10 \mu \mathrm{M}$ because it was not cytotoxic or mutagenic to HTC cells. At $24 \mathrm{~h}$, SIM treatment (cells exposed to both VA and $\mathrm{B}[\mathrm{a}] \mathrm{P}$ ) reduced the proportion of induced micronucleated cells by $57.14 \%$. At $48 \mathrm{~h}$, all VA treatments reduced the frequency of micronuclei induced by B[a]P. The greatest reduction in micronucleated cells was observed following SIM treatment (cells exposed simultaneously to VA and B[a]P for $24 \mathrm{~h}$ and analyzed after one more cell cycle) $(58.20 \%)$, followed by PRE (46.27\%), and POST (22.39\%).

The antimutagenesis mechanisms of VA have also been observed in prokaryotes. Bourgou et al. (2008) used the Ames test and found that the number of revertant bacteria

Genetics and Molecular Research 15 (4): gmr15049388 
colonies can be reduced by $70 \%$ by treatment with sodium azide and Nigella sativa plant extracts, indicating that phenolic compounds, particularly VA, exert antimutagenic activity.

When HTC cells were exposed simultaneously to VA and B[a]P, the number of induced micronuclei decreased. VA may act by reducing the toxicity of the mutagenic compound, reducing the activity of phase I enzymes, which metabolize this inert compound to its active form (benzo[a]pyrene(C)-7,8dihydrodiol-9,10-epoxide), or possibly activating phase II enzymes, which inactivate toxic cellular agents. As cells assimilate VA, the same mechanism may have occurred in the PRE. Similarly, in the POST, the cells were exposed to VA only after damage had been established, resulting in a lower reduction of micronucleated cells. These data also suggest that VA does not affect the activation of the DNA repair system. AppiahOpong et al. (2007) evaluated the inhibitory effect of VA on five phase I enzymes (CYP3A4, CYP1A2, CYP2B6, CYP2C9, and CYP2D6) and found a slight but significant inhibition (15\% on average). This finding reinforces the idea that VA may act by reducing the activity of metabolizing enzymes, which catalyze the conversion of $\mathrm{B}[\mathrm{a}] \mathrm{P}$ in its toxic form, consistent with the results obtained in the present study in response to the SIM and PRE.

Evaluation of CBPI in the mutagenicity test indicated that VA had no cytotoxic effect on the HTC cells with regards to this parameter, and the percentage of cytostasis revealed an increase in proliferating cells under all treatments $(0.15,6.16$, and $4.65 \%$ for 10,50 , and $100 \mu \mathrm{M}$ VA, respectively) compared to the CO-. In addition, no cytotoxic effect was observed for CBPI in the antimutagenesis $24-\mathrm{h}$ SIM treatment. B[a]P induced a higher percentage of cytostatic cells (16.56 and $16.27 \%$ for 24 and $48 \mathrm{~h}$, respectively), thus reducing cell proliferation. Furthermore, VA reduced this effect (increasing the number of proliferating cells by $18.14 \%$ at $24 \mathrm{~h}$ and reducing the number of cytostatic cells induced by $\mathrm{B}[\mathrm{a}] \mathrm{P}$ by $9.32,10.74$, and $7.11 \%$, respectively, in the SIM, PRE, and POST at $48 \mathrm{~h}$ ). These results indicated that VA does not exert a cytotoxic effect at concentrations up to $100 \mu \mathrm{M}$, and that at $10 \mu \mathrm{M}$, VA reduces cytotoxicity induced by $\mathrm{B}[\mathrm{a}] \mathrm{P}$ in HTC cells. In the antimutagenicity test, VA may have reduced the percentage of apoptotic cells induced by $\mathrm{B}[\mathrm{a}] \mathrm{P}$, resulting in reduced cytostasis, as evaluated by the CBPI at $48 \mathrm{~h}$. These effects of VA on cell proliferation have not yet been described in the literature.

In conclusion, VA, a phenolic compound consumed by humans mainly through their diet, has no mitochondrial toxicity in HTC cells cultured in vitro, which have a metabolism similar to that of human cells, at concentrations ranging from 1 to $100 \mu \mathrm{M}$. In addition, no effect on plasma membrane integrity was observed at concentrations ranging from 1 to $500 \mu \mathrm{M}$. Furthermore, 10 and $50 \mu \mathrm{M}$ VA exhibited no mutagenic/clastogenic potential when used in a cytokinesis-block micronucleus assay. Moreover, low concentrations of VA, such as $10 \mu \mathrm{M}$, did not present cytotoxic or antiproliferative activities and reduced the level of cytotoxicity induced by B[a]P. Additionally, this low concentration was effective at protecting the DNA from damage by reducing the percentage of micronuclei, demonstrating its marked antimutagenic potential in this assay.

\section{Conflicts of interest}

The authors declare no conflict of interest.

\section{ACKNOWLEDGMENTS}

The authors would like to thank the Coordination for the Improvement of Higher Level Personnel, CAPES, and the Laboratory of Mutagenesis and Environmental Monitoring staff of the State University of Maringá, UEM.

Genetics and Molecular Research 15 (4): gmr15049388 


\section{REFERENCES}

Alves VG, Souza AG, Chiavelli LUR, Ruiz ALTG, et al. (2016). Phenolic compounds and anticancer activity of commercial sugarcane cultivated in Brazil. An. Acad. Bras. Cienc. 88: 1201-1209. http://dx.doi.org/10.1590/0001$\underline{3765201620150349}$

Appiah-Opong R, Commandeur JNM, van Vugt-Lussenburg B and Vermeulen NPE (2007). Inhibition of human recombinant cytochrome P450s by curcumin and curcumin decomposition products. Toxicology 235: 83-91. http:// dx.doi.org/10.1016/j.tox.2007.03.007

Bourgou S, Ksouri R, Bellila A, Skandrani I, et al. (2008). Phenolic composition and biological activities of Tunisian Nigella sativa L. shoots and roots. C. R. Biol. 331: 48-55. http://dx.doi.org/10.1016/j.crvi.2007.11.001

Brindzová L, Zalibera M, Jakubík T, Mikulášová M, et al. (2009). Antimutagenic and radical scavenging activity of wheat bran. Cereal Res. Commun. 37: 45-55. http://dx.doi.org/10.1556/CRC.37.2009.1.6

Chen Y, Xu J, Yu H, Qing C, et al. (2008). Cytotoxic phenolics from Bulbophyllum odoratissimum. Food Chem. 107: 169-173. http://dx.doi.org/10.1016/j.foodchem.2007.07.077

Chou TH, Ding HY, Hung WJ and Liang CH (2010). Antioxidative characteristics and inhibition of $\alpha$-melanocytestimulating hormone-stimulated melanogenesis of vanillin and vanillic acid from Origanum vulgare. Exp. Dermatol. 19: 742-750. http://dx.doi.org/10.1111/j.1600-0625.2010.01091.x

Das A, Raychaudhuri U and Chakraborty R (2012). Cereal based functional food of Indian subcontinent: a review. J. Food Sci. Technol. 49: 665-672. http://dx.doi.org/10.1007/s13197-011-0474-1

Dhananjaya BL, Nataraju A, Rajesh R, Raghavendra Gowda CD, et al. (2006). Anticoagulant effect of Naja naja venom 5'nucleotidase: demonstration through the use of novel specific inhibitor, vanillic acid. Toxicon 48: 411-421. http:// dx.doi.org/10.1016/j.toxicon.2006.06.017

Dhananjaya BL, Nataraju A, Raghavendra Gowda CD, Sharath BK, et al. (2009). Vanillic acid as a novel specific inhibitor of snake venom 5'-nucleotidase: a pharmacological tool in evaluating the role of the enzyme in snake envenomation. Biochemistry (Mosc.) 74: 1315-1319. http://dx.doi.org/10.1134/S0006297909120037

Erdem MG, Cinkilic N, Vatan O, Yilmaz D, et al. (2012). Genotoxic and anti-genotoxic effects of vanillic acid against mitomycin C-induced genomic damage in human lymphocytes in vitro. Asian Pac. J. Cancer Prev. 13: 4993-4998. http://dx.doi.org/10.7314/APJCP.2012.13.10.4993

Gitzinger M, Kemmer C, Fluri DA, El-Baba MD, et al. (2012). The food additive vanillic acid controls transgene expression in mammalian cells and mice. Nucleic Acids Res. 40: e37. http://dx.doi.org/10.1093/nar/gkr1251

Huang SM, Hsu CL, Chuang HC, Shih PH, et al. (2008). Inhibitory effect of vanillic acid on methylglyoxal-mediated glycation in apoptotic Neuro-2A cells. Neurotoxicology 29: 1016-1022. http://dx.doi.org/10.1016/j.neuro.2008.07.002

Itoh A, Isoda K, Kondoh M, Kawase M, et al. (2009). Hepatoprotective effect of syringic acid and vanillic acid on concanavalin a-induced liver injury. Biol. Pharm. Bull. 32: 1215-1219. http://dx.doi.org/10.1248/bpb.32.1215

Jun HI, Song GS, Yang EI, Youn Y, et al. (2012). Antioxidant activities and phenolic compounds of pigmented rice bran extracts. J. Food Sci. 77: C759-C764. http://dx.doi.org/10.1111/j.1750-3841.2012.02763.x

Kanski J, Aksenova M, Stoyanova A and Butterfield DA (2002). Ferulic acid antioxidant protection against hydroxyl and peroxyl radical oxidation in synaptosomal and neuronal cell culture systems in vitro: structure-activity studies. $J$. Nutr. Biochem. 13: 273-281. http://dx.doi.org/10.1016/S0955-2863(01)00215-7

Kim SJ, Kim MC, Um JY and Hong SH (2010). The beneficial effect of vanillic acid on ulcerative colitis. Molecules 15: 7208-7217. http://dx.doi.org/10.3390/molecules 15107208

Kroymann J (2011). Natural diversity and adaptation in plant secondary metabolism. Curr. Opin. Plant Biol. 14: 246-251. http://dx.doi.org/10.1016/j.pbi.2011.03.021

Kumar S, Prahalathan P and Raja B (2011). Antihypertensive and antioxidant potential of vanillic acid, a phenolic compound in L-NAME-induced hypertensive rats: a dose-dependence study. Redox Rep. 16: 208-215. http://dx.doi. org/10.1179/1351000211Y.0000000009

Mosmann T (1983). Rapid colorimetric assay for cellular growth and survival: application to proliferation and cytotoxicity assays. J. Immunol. Methods 65: 55-63. http://dx.doi.org/10.1016/0022-1759(83)90303-4

Navarro SD, Mauro MO, Pesarini JR, Ogo FM, et al. (2015). Resistant starch: a functional food that prevents DNA damage and chemical carcinogenesis. Genet. Mol. Res. 14: 1679-1691. http://dx.doi.org/10.4238/2015.March.6.14

Palafox-Carlos H, Yahia EM and González-Aguilar GA (2012). Identification and quantification of major phenolic compounds from mango (Mangifera indica, cv. Ataulfo) fruit by HPLC-DAD-MS/MS-ESI and their individual contribution to the antioxidant activity during ripening. Food Chem. 135: 105-111. http://dx.doi.org/10.1016/j. foodchem.2012.04.103

Genetics and Molecular Research 15 (4): gmr15049388 
Prince PSM, Dhanasekar K and Rajakumar S (2011). Preventive effects of vanillic acid on lipids, bax, bcl-2 and myocardial infarct size on isoproterenol-induced myocardial infarcted rats: a biochemical and in vitro study. Cardiovasc. Toxicol. 11: 58-66. http://dx.doi.org/10.1007/s12012-010-9098-3

Russell W and Duthie G (2011). Plant secondary metabolites and gut health: the case for phenolic acids. Proc. Nutr. Soc. 70: 389-396. http://dx.doi.org/10.1017/S0029665111000152

Russell WR, Scobbie L, Labat A and Duthie GG (2009). Selective bio-availability of phenolic acids from Scottish strawberries. Mol. Nutr. Food Res. 53 (Suppl 1): S85-S91. http://dx.doi.org/10.1002/mnfr.200800302

Salvadori DMF, Ribeiro LR and Fenech M (2003). Teste do micronúcleo em células humanas in vitro. In: Mutagênese Ambiental (Ribeiro LR, Salvadori DMF and Marques EK, eds.), 1st ed., 201-224. Editora ULBRA, Canoas-RS, Brazil.

Taner G, Özkan Vardar D, Aydin S, Aytaç Z, et al. (2016). Use of in vitro assays to assess the potential cytotoxic, genotoxic and antigenotoxic effects of vanillic and cinnamic acid. Drug Chem. Toxicol. 16: 1-8. http://dx.doi.org/1 $\underline{0.1080 / 01480545.2016 .1190740}$

Zheng W and Wang SY (2001). Antioxidant activity and phenolic compounds in selected herbs. J. Agric. Food Chem. 49: 5165-5170. http://dx.doi.org/10.1021/jf010697n

Genetics and Molecular Research 15 (4): gmr15049388 